UDC 621.91.01:681.3.01:004.4

DOI: https://doi.org/10.36910/6775-2313-5352-2019-14-7

O.V. Voloshko Assistant, S. P. Vysloukh Ph.D. Assoc. Prof.

National Technical University of Ukraine "Igor Sikorsky Kyiv Polytechnic Institute"

\title{
RESEARCHING OF DETAIL'S CONSTRUCTION WITH METHOD OF FINAL ELEMENTAL ANALYSIS
}

The advantages of using computer modelling for the study of the detail's elastic-deformed state during the process of its operation are given. It is proposed to use the method of finite elements for such researches. It is shown that FEMAP is an effective software environment based on finite element analysis. An example of using the finite element method for modelling the detail's elastic state operating in conditions of alternating loads is given.

Key words: computer modelling, finite element analysis, stress-deformed detail state, system of engineering analysis of FEMAP

Introduction. At the present stage of the development of instrument making, the work of many engineers, technologists, and scientists in this field is aimed at improving the detail's performance characteristics in the process of its use. These detail's characteristics are formed during its producing. Therefore, the technological process of detail's manufacturing with the choice of rational methods of its processing, which provides the necessary parameters of the treated surfaces' quality with its maximum productivity or minimum cost, is advanced to the foreground.

Modern instrument and machine-building production is characterized by the use of a wide range of structural materials, which differ in physical and mechanical properties, which significantly affect the detail's performance characteristics.

To increase the productivity of technological processes of detail's producing with specified characteristics and to ensure the effectiveness of used equipment is possible by solving optimization problems on the basis of mathematical modelling. This will provide details with the necessary physical and mechanical parameters.

Computer modelling is one of the effective methods for studying the state of any objects. Computer models are simple and convenient for computing experiments. Computer modelling gives you the opportunity to explore objects in dynamics. At the same time, it is possible to control the researching duration, to carry out repeated tests of the initial model, to receive various characteristics of the object in numerical or graphical form, to find the optimal design solution without the production of prototype samples. In computer modelling, the method of finite elements is used, the method of finite difference, the method of node potentials, etc. [1].

The use of finite element method for today is actually the world standard for calculation of detail's construction. The main advantage of this method is its versatility, which allows using a single method to perform studies of the detail's state with different materials' properties. The flexibility of the finite element method provides a multivariate method for construction's modelling [1].

The main idea of finite element method is that any continuous value such as temperature, pressure, displacement, etc., can be approximated by a discrete model, which will be based on the set of piecewise continuous functions defined on the finite number of sub-regions. Bulk-continuous functions are determined by means of values of a continuous value in the finite number of points in a given region.

A discrete model is easy to construct if it is first assumed that the numerical values of the specified parameters in each inner region are known. Then you can go to the general case. Consequently, when constructing a discrete continuous-dimensional model, proceed as follows [2]:

- in this area, the finite number of points is fixed. These points are called nodal points or nodes;

- the value of a continuous value at each point is considered as a variable to be determined;

- the area of definition of continuous value is divided into a finite number of areas, which are called elements. These elements have common nodal points and in aggregate approximates the shape of the region;

- the continuous value is approximated on each element by a polynomial, which is determined by the nodal values of this value.

For each element it is determined by its polynomial, but the polynomials are selected in such a way that the continuity of the quantity along the elements of the element is maintained. The choice of 
the form of elements and their functions for specific tasks determines the accuracy of an approximate solution and depends on the inventiveness and skill of the researcher.

Therefore, the finite element method is a universal tool for analyzing the detail's state and, among many CAD / CAM / CAE models, the software package for finite element analysis, is important.

The modern progressive software environment for solving the engineering analysis tasks is FEMAP, which allows the creation of finite element models of components, complex products and systems, and perform the analysis of the results. FEMAP helps to clearly present a pattern of behaviour of the product under investigation [3].

\section{Target of the work}

The purpose of this work is to use the FEMAP system to create a finite element model of a detail which works in difficult operating conditions, to perform a study of its state of the parameters, to obtain a clear picture of the behaviour of the investigated structure and to perform an analysis of the results.

Generators of FEMAP grids, due to the large library of finite elements of the required form, allow creating high-quality finite elemental grids and obtaining accurate results of the solution [4]. FEMAP gives you the ability to control all grid generation parameters, such as grid step, grid creation for small details, growth rates, and accounting for small geometric elements. When complex geometry is often required modification of the grid in those areas where there should be a special accuracy of the calculation. The FEMAP Meshing Toolbox allow you to perform this modelling by changing the grid step parameters in the source model interactively. In this case, the grid will be updated automatically. In addition, by modifying the grid, using the graphic scale you can immediately analyse the quality of the created finite elements to make sure that the resulting element model satisfies the quality criteria [5].

\section{Main part}

In order to perform computer modelling, the detail "rocker" with a length of $155 \mathrm{~mm}$, a maximum width of $30 \mathrm{~mm}$ and a height of $9.5 \mathrm{~mm}$ was selected. The detail has an axial hole with a diameter of $6.1 \mathrm{~mm}$. It is made of steel 40X DSTU 7806: 2015, operates under difficult conditions of alternating loads.

The initial stage of the calculation of the element of construction, which includes the detail, is an analysis of its geometry, load conditions, material properties and the creation of a calculation model. The calculation model is a definite approximation to the real kind of detail from the material of its manufacture and the specified operating conditions. It allows performing a numerical calculation of the detail's construction based on its geometry, material, initial and boundary conditions.

The drawing of the researched detail in the FEMAP software system began with the definition of the coordinates of the "finite and transitive" points of this detail and their introduction into the program. After applying these points to the drawings, they were connected by lines, which allowed obtaining a two-dimensional detail's drawing. Then the boundary surface is constructed using the "Geometry $\rightarrow$ Boundary Surface $\rightarrow$ From Curves ..." command. From the constructed boundary surface, a solid detachment was obtained using the command Geometry $\rightarrow$ Solid $\rightarrow$ Extrude. In the future, using the same command rounded the edges of the part and made holes in the required places

Figure 1 shows the built-in geometric model of the detail «rocker».

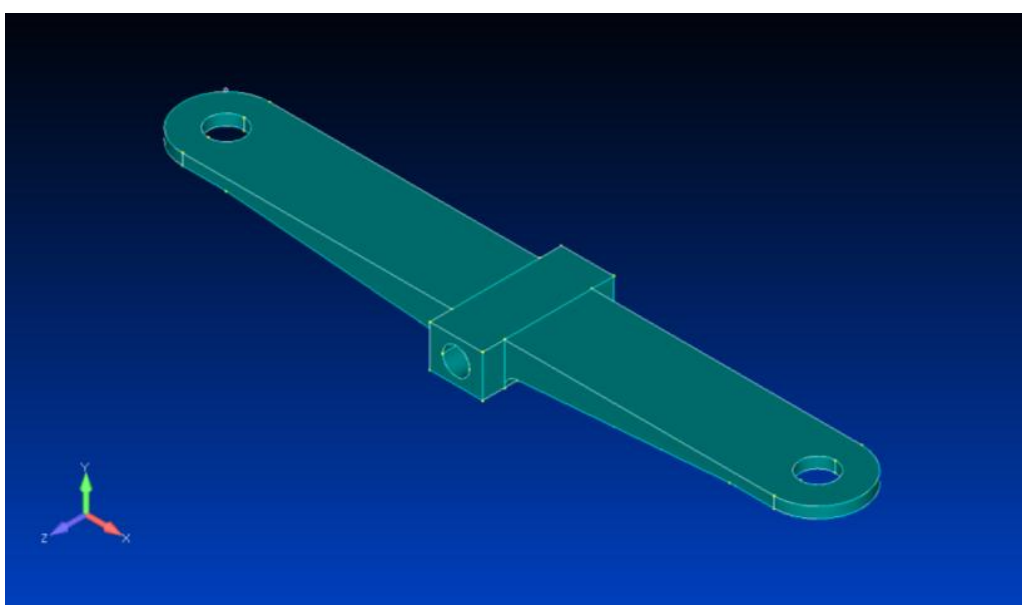

Fig. 1. Geometric model of the detail 
To create a finite-element model for the information entered earlier, the command «Model $\rightarrow$ Material ...» added the necessary characteristics of the material from which the detail was made.

The list of characteristics introduced includes all the necessary values of its physical and mechanical properties: Poisson's coefficient, material density, Young's modulus, and others. To create a finite-element grid based on the created "solid" body, the command "Mesh $\rightarrow$ Geometry $\rightarrow$ Solids ..." was used. It calls the Automesh Solids dialog box, which selected the previously created properties of the elemental grid, and installed the "Midside Nodes" option, which creates intermediate KA nodes to approximate the geometry of the body. This allows for almost precise approximation of the curvilinear surfaces, which provides a more precise solution to the issue, but leads to a significant increase in the required disk volume and RAM and time to solve the issue. By pressing the "OK" button, the generation of the elemental grid was completed, the result of which is shown in Figure 2.

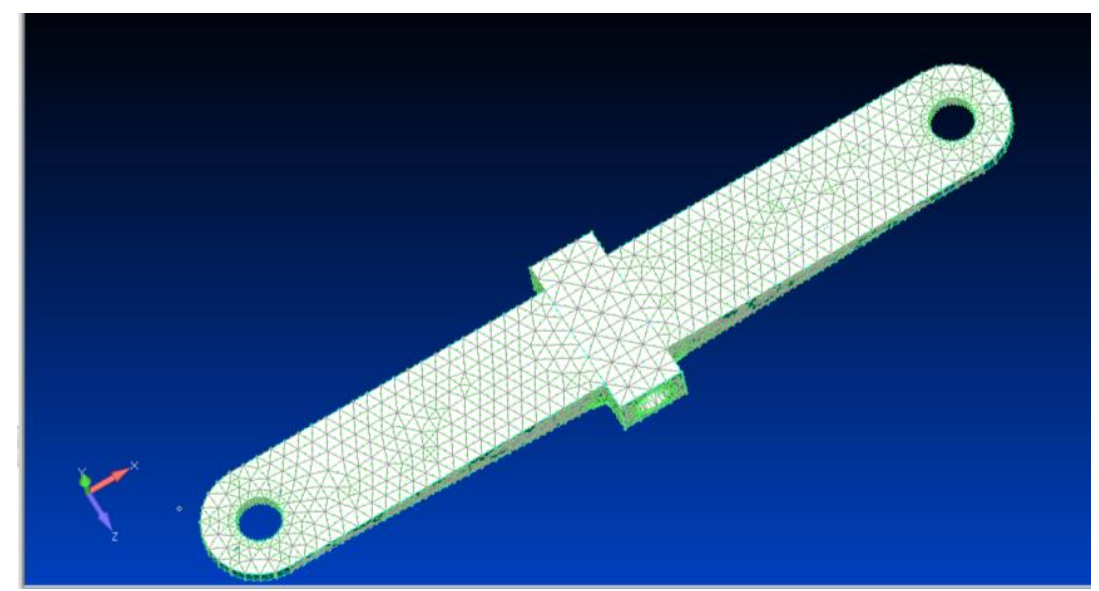

Fig. 2. Finite-element detail's model

At the next stage of the research of the detail's construction set the boundary conditions in the form of consolidations and loads. To do this, using the Model $\rightarrow$ Constraint $\rightarrow$ New Constraint Set tab, a new set of constraints was created. In the New Constraint Set dialog box in the Title column, the name of the fixation method was entered and the input was confirmed by pressing the OK button. Continuation of the research process is done by pressing the "Done" button.

The output of the standard object dialog box was executed by the commands «Model $\rightarrow$ Constraint $\rightarrow$ On Surface ...», and the choice with «Entity Selection - Enter Surface (s) to Select» commands. The choice of the fixing surface of the details was performed in the "Create Constraints on Geometry" dialog box in the "Advanced Types" section (Fig. 3). In the Create Constraints on Geometry constraints dialog, pressing button Fixed set the hard fix and confirmed it by pressing the "OK" and "Cancel" buttons.

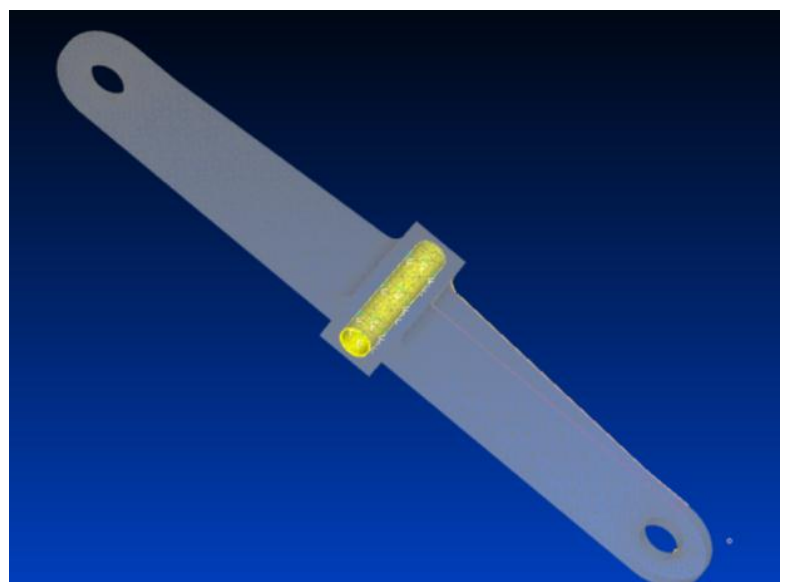

Fig. 3. Solid-state detail's model with a definite way of fixing it

A set of loads for the item was created by the command Model $\rightarrow$ Load $\rightarrow$ New Load Set, and in the New Load Set dialog in the section Title entered the name of the load set and confirmed this action by pressing the buttons "OK" and "Done". 
The "Model $\rightarrow$ Load $\rightarrow$ On Surface ..." commands caused the standard "Entity Selection" object selection dialog box to indicate the load-transfer planes on the rocker and confirmed by pressing the "OK" button. The finite-element detail's model with the load transfer planes indicated on it are shown in Figure 4.

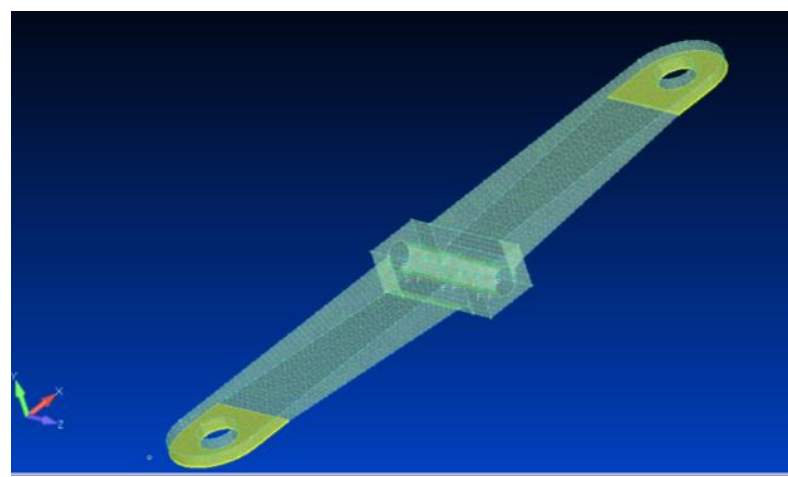

Fig. 4. Finite-element detail's model with the load-bearing planes indicated on it

In the dialog box of tasking loads Create Loads on Surfaces, values of the load were entered in the FY column, confirmation of the correct entry of the required value by the "OK" button and exit by the "Cancel" button.

An analysis of the detail's stressed state with a given load was performed using the commands «Model $\rightarrow$ Analysis $\rightarrow$ New ...». In the dialog that appears, enter the name of the analysis (Title), select the analytics program (Analysis program) and specify the type of analysis (Analysis type). After that, clicking on the "Analyze" button launched the final-element- analysis procedure for execution.

The results of the graphic view of the stressed-deformed state of the detail were obtained by pressing the "Select a Contour View" button. The reflection of equivalent stresses for the Mises hypothesis for bulk finite-element models in the form of a colour diagram was obtained on the right side of the graphical interface of the program. The final-element model of the detail with the displayed stress-deformed state is shown in Figure 5.

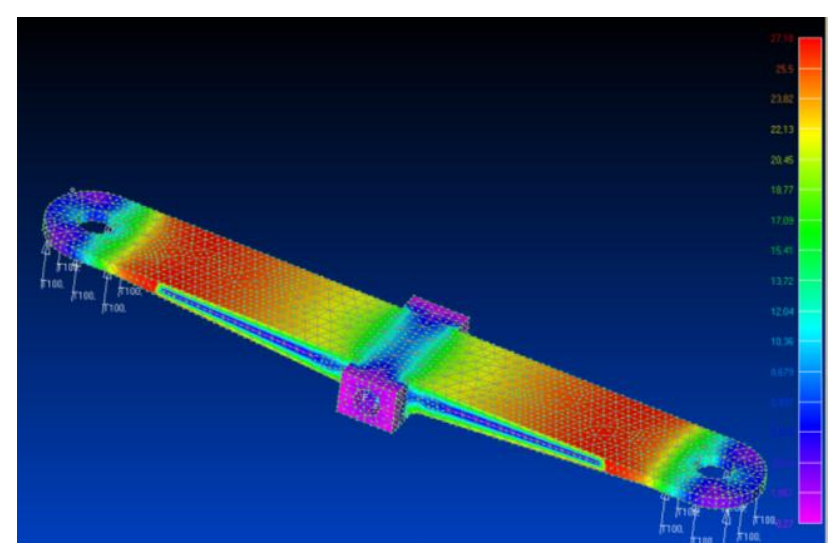

Fig. 5. Finite-element detail’s model

The system allows you to view the stress values in each particular detail area using the "Select a Criteria View" button (Fig. 6).

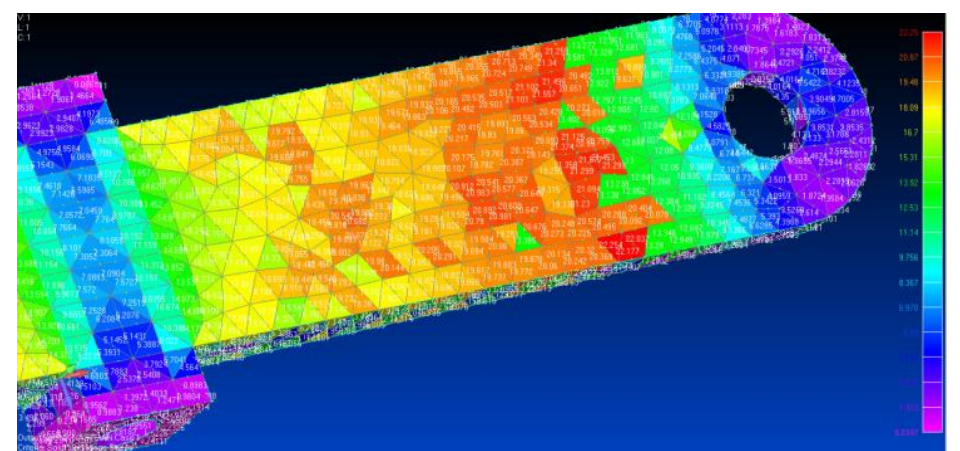

Fig. 6. The values of the stresses of the detail in the place of loads' application 
In addition, the FEMAP system allows you to obtain textual information about the results of a finite element analysis.

The results of the modelling of the stressed state of the detail allowed to determine the localization location and the values of strains and deformations that arise during the detail's operation in the assembly unit.

\section{Conclusions}

The given example of the FEMAP system using allowed to evaluate the construction of the detail "rocker" and to identify the most stressed areas and potential deformations that may occur directly in the detail's operation in the assembly unit.

The use of the FEMAP system at the stage of designing the assembly unit allows for accurate calculations of the state of each component of the product during its operation without conducting experiments. This makes it possible to reduce the cost of production for the production of experimental samples, conducting experiments, etc. Also, at the design stage of the assembly unit, it is possible to identify problem nodes of the product, make changes to its design, the parameters of individual parts, change the material from which the component is produced, etc. to ensure maximum reliability of the product as a whole.

\section{Information sources}

1. Пасічник О.А. Технології комп'ютерного проектування та моделювання напруженодеформованого стану. Вісник Хмельницького національного університету, №3, 2016 (237) - С. $172-175$.

2. Овчаренко В.А., Подлєсний С.В., Зінченко С.М. Основи методу кінцевих елементів і його застосування в інженерних розрахунках: Навчальний посібник. - Краматорськ: ДДМА, 2008. $-380 \mathrm{c}$.

3. Волошко О.В., Вислоух С.П. Комп’ютерне моделювання параметрів поверхневого шару деталей. // Збірник тез доповідей XVII Міжнародної технічної конференції «Приладобудування: стан і перспективи», ПБФ, КПІ ім. Ігоря Сікорського м. Київ, 2018. С. 63 64.

4. Барандич К.С., Вислоух С.П. Створення кінцево-елементної моделі валу та вирішення крайової задачі напружено-деформованого стану матеріалів. // Збірник наукових праць (галузеве машинобудування, будівництво)/ Полтавський національний технічний університет імені Юрія Кондратюка.- Вип. 2 (41). - Полтава: ПолтНТУ, 2014. - С. 228-232

5. Волошко О.В., Вислоух С.П. Моделювання пружного стану деталі засобами системи FEMAP. // Збірник наукових праць III Всеукраїнської науково-практичної конференції «Приладобудування та метрологія: сучасні проблеми, тенденції розвитку» м. Луцьк - 2018 р. C. 20-21.

Волошко О.В., асистент, Вислоух С. П., к.т.н., доцент

Національний технічний університет України “Київський політехнічний інститут імені Ігоря Сікорського "

\section{ДОСЛІДЖЕННЯ КОНСТРУКЦІЇ ДЕТАЛІ МЕТОДОМ КІНЦЕВО-ЕЛЕМЕНТНОГО АНАЛІЗУ}

Наведено переваги використання комп'ютерного моделювання для дослідження пружно-деформований стан деталі в процесі ї̈ експлуатаиії. Запропоновано для таких досліджень використовувати метод скінченних елементів. Показано, що ефективним програмним середовищем, яке базується на кінцево-елементному аналізі, є система FEMAP. Наведена приклад використання методу скінченних елементів для моделювання пружного стану деталі, що пращює в умовах знакозмінних навантажень.

Ключові слова: комп'ютерне моделювання, кінцево-елементний аналіз, напруженодеформований стан деталі, система інженерного аналізу FЕМАР. 
Волошко О.В., ассистент, Выслоух С. П., к.т.н., доцент

Национальный технический университет Украины “Киевский политехнический институт имени Игоря Сикорского "

\section{ИСЛЕДОВАНИЕ КОНСТРУКЦИИ ДЕТАЛИ МЕТОДОМ КОНЕЧНО-ЭЛЕМЕНТНОГО} АНАЛИЗА

Приведень преимущества использования компьютерного моделирования для исследования напряженно-деформированного состояния детали в процессе ее эксплуатаџии. Предложено для таких исследований использовать метод конечных элементов. Показано, что эффективной программной средой, основанной на конечно-элементном анализе, является система FЕМАР. Приведен пример использования метода конечных элементов для моделирования упругого состояния детали, которая работает в условиях знакопеременньх нагрузок

Ключевые слова: компьютерное моделирование, конечно-элементный анализ, напряженно-деформированное состояние детали, система инженерного анализа FЕМАР. 